\title{
VALIDATION OF PWR-FUEL CODE FOR STATIC PARAMETERS IN THE LWR CORE BENCHMARK
}

\author{
Iman Kuntoro ${ }^{1 *}$, Surian Pinem ${ }^{1}$,Tagor Malem Sembiring ${ }^{2}$ \\ ${ }^{1}$ Center for Nuclear Reactor Technology and Safety, BATAN \\ KawasanPuspiptek Building No. 80, Tangerang Selatan 15310, Indonesia \\ ${ }^{2}$ Center for Nuclear Energy System Assesment, BATAN \\ Jalan Kuningan Barat, Mampang Prapatan, Jakarta 12710, Indonesia \\ E-mail: imank@batan.go.id \\ Diterima editor: 27 September 2018 \\ Diperbaiki: 10 Oktober 2018 \\ Disetujui untuk publikasi: 11 Oktober 2018
}

\begin{abstract}
VALIDATION OF PWR-FUEL CODE FOR STATIC PARAMETERS IN THE LWR CORE BENCHMARK. The PWR-FUEL code is a multi dimensional, multi group diffusion code with nodal and finite difference methods. The code will be used to calculate the fuel management of PWR reactor core. The result depends on the accuracy of the codes in producing the core effective multiplication factor and power density distribution. The objective of this research is to validate the PWR-FUEL code for those cases. The validation are carried out by benchmarking cores of IAEA-2D, KOERBERG-2D and BIBLIS2D. The all three cases have different characteristics, thus it will result in a good accuracy benchmarking. The calculation results of effective multiplication factor have a maximum difference of $0.014 \%$, which is greater than the reference values. For the power peaking factor, the maximum deviation is $1.75 \%$ as compared to the reference values. Those results show that the accuracy of PWR-FUEL in calculating the static parameter of PWR reactor benchmarks are very satisfactory.
\end{abstract}

Keywords: Validation, PWR-FUEL code, static parameter.

\section{ABSTRAK}

VALIDASI PROGRAM PWR-FUEL UNTUK PARAMETER STATIK PADA TERAS BENCHMARK LWR. Program PWR-FUEL adalah program difusi multi-dimensi, multi-kelompok dengan metode nodal dan metode beda hingga. Program ini akan digunakan untuk menghitung manajemen bahan bakar teras reaktor PWR. Akurasi manajemen bahan bakar teras PWR tergantung pada akurasi program dalam memprediksi faktor multiplikasi efektif teras dan distribusi rapat daya. Untuk itu dilakukan validasi program PWR-FUEL sebagai tujuan dalam penelitian ini. Validasi PWR-FUEL dilakukan menggunakan teras benchmark IAEA-2D, KOERBERG-2D dan BIBLIS-2D. Ketiga kasus ini mempunyai karaktristik yang berbeda sehingga akan memberikan hasil benchmark yang akurat. Hasil perhitungan faktor multiplikasi efektif terdapat perbedaan maksimum adalah 0,014\% lebih besar dari referensi. Sedangkan untuk perhitungan faktor puncak daya, terdapat perbedaan maksimum $1,75 \%$ dibanding harga referensi. Hasil perhitungan menunjukkan bahwa akurasi paket program PWR-FUEL dalam menghitung parameter statik benchmark reaktor PWR menunjukkan hasil yang sangat memuaskan.

Kata kunci: Validasi, program PWR-FUEL, parameter statik

DOI: $\underline{10.17146 / \mathrm{tdm} .2018 .20 .3 .4650}$ 


\section{INTRODUCTION}

In the five year plan $2014-2019$, BATAN has research and development program on reactor safety and technology. It is expected that Nuclear Power Plant (NPP) can synergize and form a mutualistic symbiosis between fossil and non-fossil energy. Therefore, it can contribute to the fulfillment of national energy demands in order to support the sustainability. To support the nuclear R\&D program, especially the first nuclear power plant in Indonesia, BATAN as a nuclear R\&D institution has undertaken several plans and sustainable stages. One of them is the evaluation and analysis of reactor core of nuclear power plant. Some analysis on PWR core have been done, either for static parameter [1-4] and dynamic parameter [5-7]. In addition, research on transient analysis on PWR core has been conducted $[8,9]$. For the next research activities, the study will be focused on the in-core fuel management of PWR.

The fuel management issues in the reactor core are so complex, therefore it needs to be done in some calculation steps using appropriate method. The selection of an analytical model for reactor fuel management is more difficult than that of a research reactor because the number of variable calculations on the reactor core is overwhelming. In-core fuel management covers activities of core configuration building, burn up determination, operation cycle duration and fuel loading pattern in order to fulfill the nuclear safety by providing enough shut down margin and economical operation in a long duration of operation cycle. There are several methods which have been developed globally for those purposes [10-13].

In this study, PWR-FUEL code [14] will be used for the calculation of the in-core fuel management. The PWR-FUEL is based on multi-group nodal diffusion (NODAL) and finite difference diffusion method (FDM). The Nodal method is required because one fuel device is relatively very large in size. Since all fuel elements in the core have the same size, thus all nodes have the same size geometry. Calculation of reactor core parameters on PWR with nodal method gave excellent results $[15,16]$ thus this in-core fuel management used nodal method. The PWRFUEL code has been verified by generic PWR core of 1000 MWe [17]. The objective of this work is to find that the main feature of the code has a very good function for core management calculations of PWR. In this research work, the verification is focused on the accuration of PWRFUEL code for effective multiplication factor $\left(k_{e f f}\right)$ and power density distribution, since the accuracy of fuel management calculation exactly denpends on those accuracy of those parameters.

Core benchmark is selected based on the considerations of variation of 2-dimension geometry (2D) and it is close to the real PWR core condition. For this purpose, the selected benchmark cores are IAEA-2D, BIBLIS-2D and KOEBERG-2D cores [18]. Those core benchmarks have been widely used for validity test of core neutronic parameter methods [19-21]. The validity result will determine the accuracy of PWR-FUEL codes in calculating the in-core fuel managements of the PWR reactor.

\section{DESCRIPTION OF PWR BENCHMARK CASES}

As obviously mentioned above that there are three cases of core benchmark namely IAEA2D, KOEBERG-2D and BIBLIS-2D cores. Case of IAEA-2D is for a light water reactor, LWR core contains 2 zone of core from 177 fuel assemblies with $20 \mathrm{~cm}$ thick of water reflector and vacuum as the outer boundary conditions. This case results in a strong perturbation due to a high gradient thermal flux of the absorber rods at the core-reflector interface. This case is widely used to validate the accuracy of codes to solve the diffusion equation of two group of neutron energy. The core configuration of IAEA-2D is illustrated in Fig. 1 and the associated cross section data is presented Table 1. 


\begin{tabular}{|c|c|c|c|c|c|c|c|c|}
\hline 3 & 2 & 2 & 2 & 3 & 2 & 2 & 1 & 4 \\
\hline 2 & 2 & 2 & 2 & 2 & 2 & 2 & 1 & 4 \\
\hline 2 & 2 & 2 & 2 & 2 & 2 & 1 & 1 & 4 \\
\hline 2 & 2 & 2 & 2 & 2 & 2 & 1 & 4 & 4 \\
\hline 3 & 2 & 2 & 2 & 3 & 1 & 1 & 4 & \\
\hline 2 & 2 & 2 & 2 & 1 & 1 & 4 & 4 & \\
\hline 2 & 2 & 1 & 1 & 1 & 4 & 4 & & \\
\hline 1 & 1 & 1 & 4 & 4 & 4 & & & \\
\hline 4 & 4 & 4 & 4 & & & & & \\
\hline
\end{tabular}

Fig. 1. IAEA-2D core configuration[18].

Table 1. Cross section data for IAEA-2D [18].

\begin{tabular}{cccccc}
\hline Zone & Group & $\mathrm{D}_{\mathrm{g}}$ & $\Sigma_{\mathrm{ag}}$ & $v \Sigma_{\mathrm{fg}}$ & $\Sigma_{\mathrm{sg} 1}$ \\
\hline 1 & 1 & 1.5 & 0.010120 & 0.000 & 0.000 \\
& 2 & 0.4 & 0.080032 & 0.135 & 0.020 \\
2 & 1 & 1.5 & 0.010120 & 0.000 & 0.000 \\
& 2 & 0.4 & 0.085032 & 0.135 & 0.020 \\
3 & 1 & 1.5 & 0.010120 & 0.000 & 0.000 \\
& 2 & 0.4 & 0.130032 & 0.135 & 0.200 \\
& & & & & \\
4 & 1 & 2.0 & 0.000160 & 0.000 & 0.000 \\
& 2 & 0.3 & 0.010024 & 0.000 & 0.040 \\
\hline
\end{tabular}

Case of 2D-KOEBERG is to obtain the capability of the code for multigroup of energy, a benchmark of 4 group neutron energy with real cross sections including up and down scattering. Specifically, initial core of PWR KOEBERG Unit-1 was taken as the model. The model consists of 157 fuel assemblies which are homogenized in 3 different enrichments and 3 different burnable absorber loading. Each assembly has $21.608 \mathrm{~cm}$ of width. The core is surrounded by $21.608 \mathrm{~cm}$ homogenized reflector from 2.8575 baffles and $18.7505 \mathrm{~cm}$ of borated water, and vacuum as the outer boundary condition. Core configuration and cross section data are presented in Fig. 2 and Table 2. 


\begin{tabular}{|c|c|c|c|c|c|c|c|c|}
\hline 1 & 3 & 1 & 3 & 1 & 2 & 1 & 4 & 7 \\
\hline 3 & 1 & 3 & 1 & 2 & 1 & 6 & 4 & 7 \\
\hline 1 & 3 & 1 & 2 & 1 & 3 & 4 & 7 & 7 \\
\hline 3 & 1 & 2 & 1 & 3 & 5 & 4 & 7 & \\
\hline 1 & 2 & 1 & 3 & 1 & 4 & 7 & 7 & \\
\hline 2 & 1 & 3 & 5 & 4 & 7 & 7 & & \\
\hline 1 & 6 & 4 & 4 & 7 & 7 & & & \\
\hline 4 & 4 & 7 & 7 & 7 & & & & \\
\hline 7 & 7 & 7 & & & & & & \\
\hline
\end{tabular}

Fig. 2. KOEBERG core configuration[18].

Table 2. Four energy group cross section data for KOEBERG case[18].

\begin{tabular}{|c|c|c|c|c|c|c|c|c|}
\hline Zone & Group & $\mathrm{D}_{\mathrm{g}}$ & $\Sigma_{\text {ag }}$ & $v \Sigma_{\mathrm{fg}}$ & $\Sigma_{\mathrm{sg} 1}$ & $\Sigma_{\mathrm{sg} 2}$ & $\Sigma_{\mathrm{sg} 3}$ & $\Sigma_{\mathrm{sg} 4}$ \\
\hline \multirow[t]{4}{*}{1} & 1 & 2.491869 & 0.003654 & 0.008228 & 0.000 & 0.000 & 0.000 & 0.000 \\
\hline & 2 & 1.045224 & 0.002124 & 0.000536 & 0.063789 & 0.000 & 0.000 & 0.000 \\
\hline & 3 & 0.677407 & 0.019908 & 0.007058 & 0.000486 & 0.064381 & 0.000 & 0.001245 \\
\hline & 4 & 0.375191 & 0.067990 & 0.083930 & 0.000 & 0.000003 & 0.050849 & 0.000 \\
\hline \multirow[t]{4}{*}{2} & 1 & 2.492653 & 0.003685 & 0.008295 & 0.000 & 0.000 & 0.000 & 0.000 \\
\hline & 2 & 1.049844 & 0.002215 & 0.000713 & 0.063112 & 0.000 & 0.000 & 0.000 \\
\hline & 3 & 0.676610 & 0.022012 & 0.009230 & 0.000478 & 0.063078 & 0.000 & 0.001543 \\
\hline & 4 & 0.379451 & 0.085052 & 0.108244 & 0.000 & 0.000003 & 0.048420 & 0.000 \\
\hline \multirow[t]{4}{*}{3} & 1 & 2.491978 & 0.003684 & 0.008459 & 0.000 & 0.000 & 0.000 & 0.000 \\
\hline & 2 & 1.051910 & 0.002221 & 0.000713 & 0.062765 & 0.000 & 0.000 & 0.000 \\
\hline & 3 & 0.677084 & 0.022403 & 0.009214 & 0.000473 & 0.062404 & 0.000 & 0.001598 \\
\hline & 4 & 0.381453 & 0.088077 & 0.108087 & 0.000 & 0.000003 & 0.047549 & 0.000 \\
\hline \multirow[t]{4}{*}{4} & 1 & 2.492535 & 0.003740 & 0.008409 & 0.000 & 0.000 & 0.000 & 0.000 \\
\hline & 2 & 1.045298 & 0.002299 & 0.000923 & 0.063737 & 0.000 & 0.000 & 0.000 \\
\hline & 3 & 0.674684 & 0.022621 & 0.011714 & 0.000486 & 0.064330 & 0.000 & 0.001630 \\
\hline & 4 & 0.374240 & 0.091000 & 0.133600 & 0.000 & 0.000003 & 0.049518 & 0.000 \\
\hline \multirow[t]{4}{*}{5} & 1 & 2.492329 & 0.003730 & 0.008409 & 0.000 & 0.000 & 0.000 & 0.000 \\
\hline & 2 & 1.051953 & 0.002315 & 0.000921 & 0.062737 & 0.000 & 0.000 & 0.000 \\
\hline & 3 & 0.675683 & 0.023822 & 0.011675 & 0.000473 & 0.062376 & 0.000 & 0.001797 \\
\hline & 4 & 0.380606 & 0.100246 & 0.134282 & 0.000 & 0.000003 & 0.046859 & 0.000 \\
\hline \multirow[t]{4}{*}{6} & 1 & 2.491521 & 0.003740 & 0.008400 & 0.000 & 0.000 & 0.000 & 0.000 \\
\hline & 2 & 1.055029 & 0.002321 & 0.000921 & 0.062386 & 0.000 & 0.000 & 0.000 \\
\hline & 3 & 0.676197 & 0.024196 & 0.011651 & 0.000468 & 0.061696 & 0.000 & 0.001852 \\
\hline & 4 & 0.382434 & 0.103283 & 0.133974 & 0.000 & 0.000003 & 0.046005 & 0.000 \\
\hline \multirow[t]{4}{*}{7} & 1 & 2.119737 & 0.000466 & 0.000 & 0.000 & 0.000 & 0.000 & 0.000 \\
\hline & 2 & 0.980098 & 0.000263 & 0.000 & 0.042052 & 0.000 & 0.000 & 0.000 \\
\hline & 3 & 0.531336 & 0.004282 & 0.000 & 0.000322 & 0.044589 & 0.000 & 0.000978 \\
\hline & 4 & 1.058029 & 0.116918 & 0.000 & 0.000 & 0.000 & 0.052246 & 0.000 \\
\hline
\end{tabular}


Case of 2D-BIBLIS contains a realistic problem and a very high of nonseparable 2-group of energy that represents the actual PWR with checker-board-loaded core. Fuel assembly is homogenized by width of $23.1226 \mathrm{~cm}$ and 7 different material compositions of cores and surrounded by $23.1226 \mathrm{~cm}$ of homogenized reflector from baffle and water, with vacuum as outer boundary condition. The core configuration and cross section data are presented in Fig. 3 and Table 3 .

\begin{tabular}{|c|c|c|c|c|c|c|c|c|}
\hline 1 & 8 & 2 & 6 & 1 & 7 & 1 & 4 & 3 \\
\hline 8 & 1 & 8 & 2 & 8 & 1 & 1 & 4 & 3 \\
\hline 2 & 8 & 1 & 8 & 2 & 7 & 1 & 4 & 3 \\
\hline 6 & 2 & 8 & 2 & 8 & 1 & 8 & 4 & 3 \\
\hline 1 & 8 & 2 & 8 & 2 & 5 & 4 & 3 & 3 \\
\hline 7 & 1 & 7 & 1 & 5 & 4 & 4 & 3 & \\
\hline 1 & 1 & 1 & 8 & 4 & 4 & 3 & 3 & \\
\hline 4 & 4 & 4 & 4 & 3 & 3 & 3 & & \\
\hline 3 & 3 & 3 & 3 & 3 & & & & \\
\hline
\end{tabular}

Fig. 3. BIBLIS core configuration[18].

Tabel 3. Cross section data for BIBLIS core[18].

\begin{tabular}{|c|c|c|c|c|c|}
\hline Zone & Group & $\mathrm{D}_{\mathrm{g}}$ & $\Sigma_{a g}$ & $v \Sigma_{\mathrm{fg}}$ & $\Sigma_{\mathrm{sg} 1}$ \\
\hline \multirow[t]{2}{*}{1} & 1 & 1.4360 & 0.0095042 & 0.0058708 & 0.000 \\
\hline & 2 & 0.3635 & 0.075058 & 0.0960670 & 0.017754 \\
\hline \multirow[t]{2}{*}{2} & 1 & 1.4366 & 0.0096785 & 0.0061908 & 0.000 \\
\hline & 2 & 0.3636 & 0.0784360 & 0.1035800 & 0.017621 \\
\hline \multirow[t]{2}{*}{3} & 1 & 1.3200 & 0.0026562 & 0.000 & 0.000 \\
\hline & 2 & 1.4389 & 0.0715960 & 0.000 & 0.023106 \\
\hline \multirow[t]{2}{*}{4} & 1 & 1.4389 & 0.0103630 & 0.0074527 & 0.000 \\
\hline & 2 & 0.3638 & 0.0914080 & 0.1323600 & 0.017101 \\
\hline \multirow[t]{2}{*}{5} & 1 & 1.4381 & 0.0100030 & 0.0061980 & 0.000 \\
\hline & 2 & 0.3665 & 0.0848280 & 0.1035800 & 0.017290 \\
\hline \multirow[t]{2}{*}{6} & 1 & 1.4385 & 0.0101320 & 0.0064285 & 0.000 \\
\hline & 2 & 0.3665 & 0.0873140 & 0.1091100 & 0.017192 \\
\hline \multirow[t]{2}{*}{7} & 1 & 1.4389 & 0.0101650 & 0.0061908 & 0.000 \\
\hline & 2 & 0.3679 & 0.0880240 & 0.1035800 & 0.017125 \\
\hline \multirow[t]{2}{*}{8} & 1 & 1.4393 & 0.0102940 & 0.0064285 & 0.000 \\
\hline & 2 & 0.3680 & 0.0905100 & 0.1091100 & 0.017027 \\
\hline
\end{tabular}




\section{METHODOLOGY}

The PWR-FUEL code required group of constant data of diffussion coefficient D, absorption cross section $\Sigma_{a}$ and production cross section $v \Sigma_{f}$. These groups of constant data are already available for each case of benchmark.

Core calculations were then done to obtain the effective multiplication factor $k_{\text {eff }}$ and radial power peaking factor RPPF. The $k_{\text {eff }}$ was used to determine the core reactivity, while RPPF was used to know the radially distribution of the heat generation in the core.

In nodal calculations, node of $1 \times 1$ in each fuel assembly was used. As for finite different methods, mesh of less than $2 \mathrm{~cm}$ was used for all cases. Those results were then compared to the reference values.

\section{RESULTS AND DISCUSSION}

Code validation by several core configurations and calculation models is very important to ensure that the code is properly suitable for PWR core. Criticallity calculations of core benchmark by PWR-FUEL code and reference values [18] are presented in Table 4. It is found that the deviation to the reference is maximum at the KOEBERG core which is $0.014 \%$. Meanwhile, the deviations are below that value for others cores. It clearly shows that the PWR-FUEL code is very accurate to calculate effective multiplication factor.

Table 4. Benchmark resultsof PWR-FUEL Code.

\begin{tabular}{cccc}
\hline $\begin{array}{c}\text { Benchmark } \\
\text { Case }\end{array}$ & Reference & $\begin{array}{c}\text { Effective multiplication factor }\left(k_{e f f}\right) \\
\text { NODAL Method }\end{array}$ & FDM Method \\
\hline IAEA-2D & 1.029585 & 1.029600 & 1.029492 \\
& & $(0.001 \%)$ & $(0.009 \%)$ \\
KOEBERG-2D & 1.007954 & 1.008100 & 1.008003 \\
& & $(-0.014 \%)$ & $(-0.004 \%)$ \\
BIBLIS-2D & 1.025110 & 1.0252000 & 1.0251351 \\
& & $(-0.008 \%)$ & $(-0.002 \%)$ \\
\hline
\end{tabular}

The local power density in the hot channel of fuel assemblies shall be accurately calculated to convince that this value is still below the melting point. Power peaking factor is defined as the maximum local power density devided by average power density in the core. Calculations of radial power peaking factor (RPPF) for core IAEA-2D are presented in Fig. 4. The maximum difference of RPPF is about 0.012 or $0.91 \%$ which has a good agreement with the reference values. 


\begin{tabular}{|c|c|c|c|c|c|c|c|}
\hline 0.745 & 1.309 & 1.454 & 1.211 & 0.610 & 0.934 & 0.934 & 0.754 \\
\hline 0.744 & 1.297 & 1.443 & 1.201 & 0.611 & 0.933 & 0.938 & 0.760 \\
\hline 0.001 & 0.012 & 0.011 & 0.010 & -0.001 & 0.001 & -0.004 & -0.006 \\
\hline 1.309 & 1.435 & 1.479 & 1.315 & 1.069 & 1.036 & 0.950 & 0.735 \\
\hline 1.297 & 1.426 & 1.472 & 1.310 & 1.065 & 1.037 & 0.954 & 0.743 \\
\hline 0.012 & 0.009 & 0.008 & 0.005 & 0.004 & -0.001 & -0.004 & -0.008 \\
\hline 1.453 & 1.479 & 1.469 & 1.345 & 1.179 & 1.070 & 0.975 & 0.692 \\
\hline 1.443 & 1.472 & 1.462 & 1.341 & 1.178 & 1.073 & 0.977 & 0.696 \\
\hline 0.001 & 0.008 & 0.007 & 0.004 & 0.001 & -0.003 & -0.002 & -0.004 \\
\hline 1.211 & 1.314 & 1.134 & 1.192 & 0.967 & 0.906 & 0.846 & \\
\hline 1.201 & 1.310 & 1.341 & 1.191 & 0.965 & 0.913 & 0.856 & \\
\hline 0.010 & 0.004 & -0.207 & 0.001 & 0.002 & -0.007 & -0.010 & \\
\hline 0.610 & 1.069 & 1.179 & 0.967 & 0.470 & 0.685 & 0.597 & \\
\hline 0.611 & 1.065 & 1.178 & 0.965 & 0.474 & 0.688 & 0.604 & \\
\hline-0.001 & 0.004 & 0.001 & 0.002 & -0.004 & -0.003 & -0.007 & \\
\hline 0.935 & 1.036 & 1.070 & 0.906 & 0.685 & 0.585 & & \\
\hline 0.933 & 1.037 & 1.073 & 0.913 & 0.688 & 0.588 & & \\
\hline 0.002 & -0.001 & -0.003 & -0.007 & -0.003 & -0.003 & & \\
\hline 0.585 & 0.950 & 0.975 & 0.846 & 0.597 & & & \\
\hline 0.938 & 0.954 & 0.977 & 0.856 & 0.604 & & \multirow{4}{*}{\multicolumn{2}{|c|}{$\begin{array}{l}\text { Reference } \\
\text { PWR-FUEL } \\
\text { Difference }\end{array}$}} \\
\hline-0.353 & -0.004 & -0.002 & -0.010 & -0.007 & & & \\
\hline 0.754 & 0.735 & 0.692 & & & & & \\
\hline 0.760 & 0.743 & 0.696 & & & & & \\
\hline-0.006 & -0.008 & -0.004 & & & & & \\
\hline
\end{tabular}

Fig. 4. RPPF comparison of PWR-FUEL calculationto IAEA-2D reference core.

Group neutron flux and power distribution calculation results by PWR-FUEL with nodal and finite difference methods are illustrated in Figures 5 and 6 . The both methodes clearly show that there is no significant different results. Additionally, for IAEA-2D case, there is a great netron flux pertubation due to neutron absorption in the control rod region.

It can be said that PWR-FUEL code has a very good accuracy with the IAEA-2D model, because it has a maximum deviation to the reference values of effective multiplication factor of $0.001 \%$ and RPPF of $0.91 \%$.

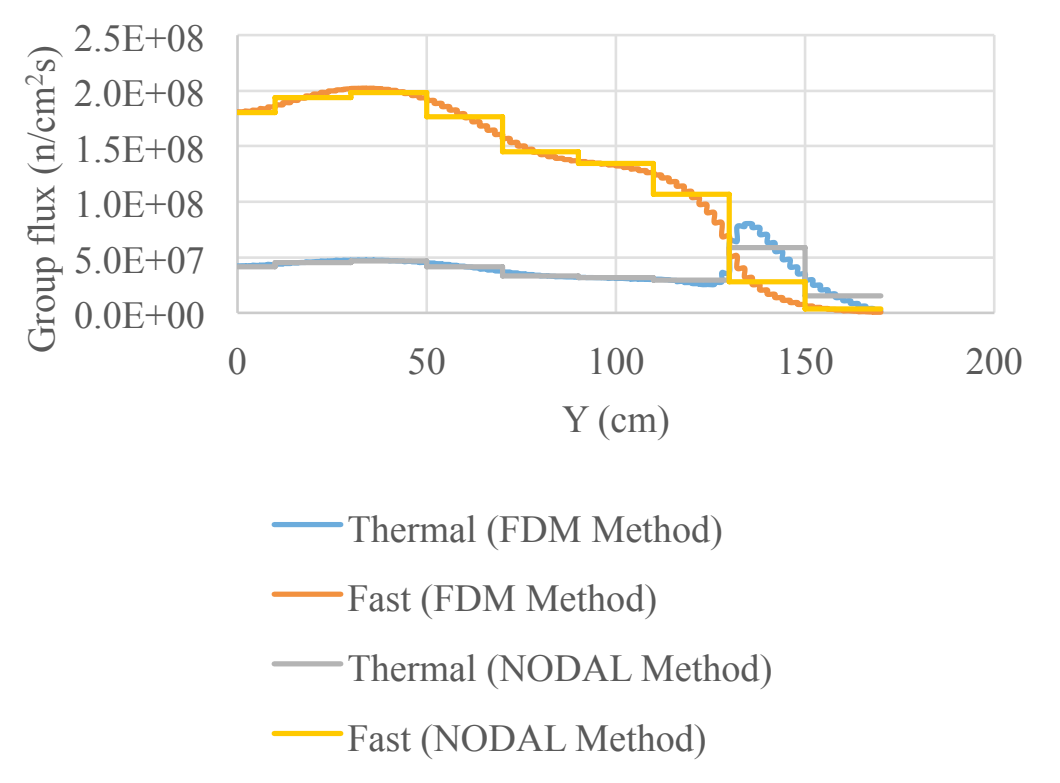

Fig. 5. Group neutron flux distribution at $\mathrm{X}=60 \mathrm{~cm}$ for the IAEA-2D. 


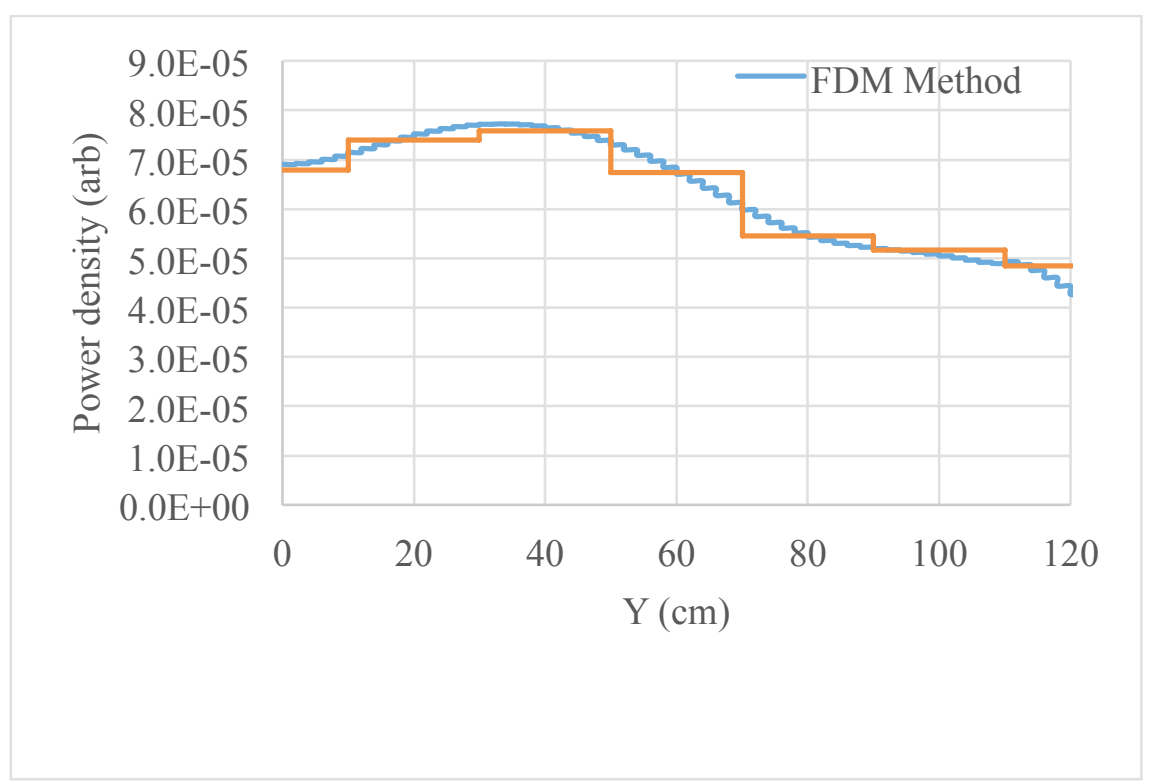

Fig. 6. Power density distribution at $\mathrm{X}=60 \mathrm{~cm}$ for the IAEA-2D.

Results of radial power peaking factor calculations by PWR-FUEL on KOEBERG-2D core are presented in Fig. 7. It shows a maximum deviation of 0.015 or $1.52 \%$ to the reference value.

\begin{tabular}{|c|c|c|c|c|c|c|c|}
\hline 1.005 & 1.085 & 1.044 & 1.163 & 1.131 & 1.214 & 0.959 & 0.833 \\
\hline 0.993 & 1.078 & 1.033 & 1.159 & 1.125 & 1.215 & 0.964 & 0.841 \\
\hline 0.012 & 0.007 & 0.011 & 0.004 & 0.006 & -0.001 & -0.005 & -0.008 \\
\hline 1.085 & 1.026 & 1.130 & 1.105 & 1.243 & 1.061 & 1.042 & 0.642 \\
\hline 1.078 & 1.015 & 1.124 & 1.097 & 1.240 & 1.060 & 1.054 & 0.644 \\
\hline 0.007 & 0.011 & 0.006 & 0.008 & 0.003 & 0.001 & -0.012 & -0.002 \\
\hline 1.044 & 1.130 & 1.092 & 1.223 & 1.058 & 1.039 & 0.968 & \\
\hline 1.033 & 1.124 & 1.083 & 1.219 & 1.055 & 1.046 & 0.972 & \\
\hline 0.011 & 0.006 & 0.009 & 0.004 & 0.003 & -0.007 & -0.004 & \\
\hline 1.163 & 1.105 & 1.223 & 1.036 & 0.998 & 0.981 & 0.650 & \\
\hline 1.159 & 1.097 & 1.219 & 1.032 & 1.004 & 0.996 & 0.649 & \\
\hline 0.004 & 0.008 & 0.004 & 0.004 & -0.006 & -0.015 & 0.001 & \\
\hline 1.131 & 1.243 & 1.058 & 0.998 & 0.786 & 0.667 & & \\
\hline 1.125 & 1.240 & 1.055 & 1.004 & 0.798 & 0.669 & & \\
\hline 0.006 & 0.003 & 0.003 & -0.006 & -0.012 & -0.002 & & \\
\hline 1.124 & 1.061 & 1.039 & 0.981 & 0.667 & & & \\
\hline 1.215 & 1.060 & 1.046 & 0.996 & 0.669 & & & \\
\hline-0.090 & 0.001 & -0.007 & -0.015 & -0.002 & & & \\
\hline 0.959 & 1.042 & 0.968 & 0.650 & & & & \\
\hline 0.964 & 1.054 & 0.972 & 0.649 & & & & \\
\hline-0.005 & -0.012 & -0.004 & 0.001 & & & & \\
\hline 0.833 & 0.642 & & & & & \multirow{3}{*}{\multicolumn{2}{|c|}{$\begin{array}{l}\text { Reference } \\
\text { PWR-FUEL } \\
\text { Difference }\end{array}$}} \\
\hline 0.841 & 0.644 & & & & & & \\
\hline-0.008 & -0.002 & & & & & & \\
\hline
\end{tabular}

Fig. 7. RPPF comparison of PWR-FUEL results to KOEBERG reference core.

Calculation results of group neutron flux and radial power peaking factors of KOEBERG core by PWR-FUEL code with nodal and finite difference methods are presented in Fig. 8 and Fig. 9. It shows again that there is no significant differences between those two methods.

Case of KOEBERG has 4 groups of neutron energy which means better than that of case of IAEA 2 group. Core benchmark KOEBERG represents core of PWR Koeberg Unit-1 at beginning of cycle (BOC), so, it represents a real condition of reactor operation. By having a deviation of 
$0.014 \%$ for effective multiplication factor and of $1.52 \%$ for RPPF to the reference values, the PWR-FUEL code shows a good performance for 4 group of neutron energy cases.

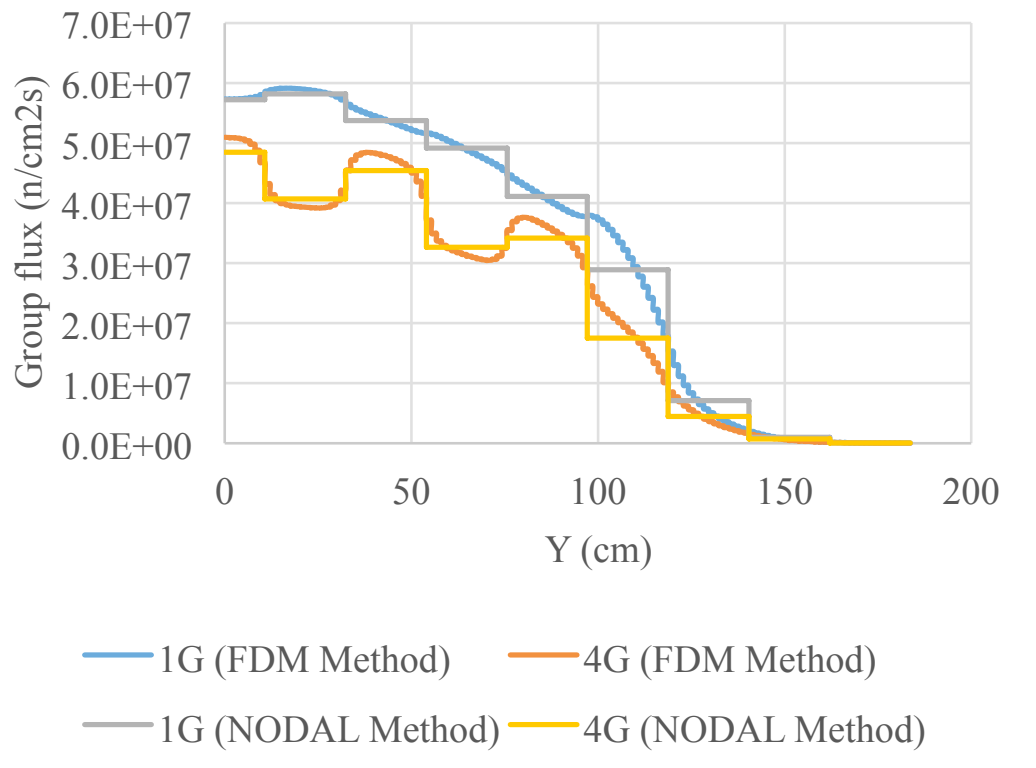

Fig. 8. Group neutron flux distribution at $\mathrm{X}=0 \mathrm{~cm}$ for the KOEBERG.

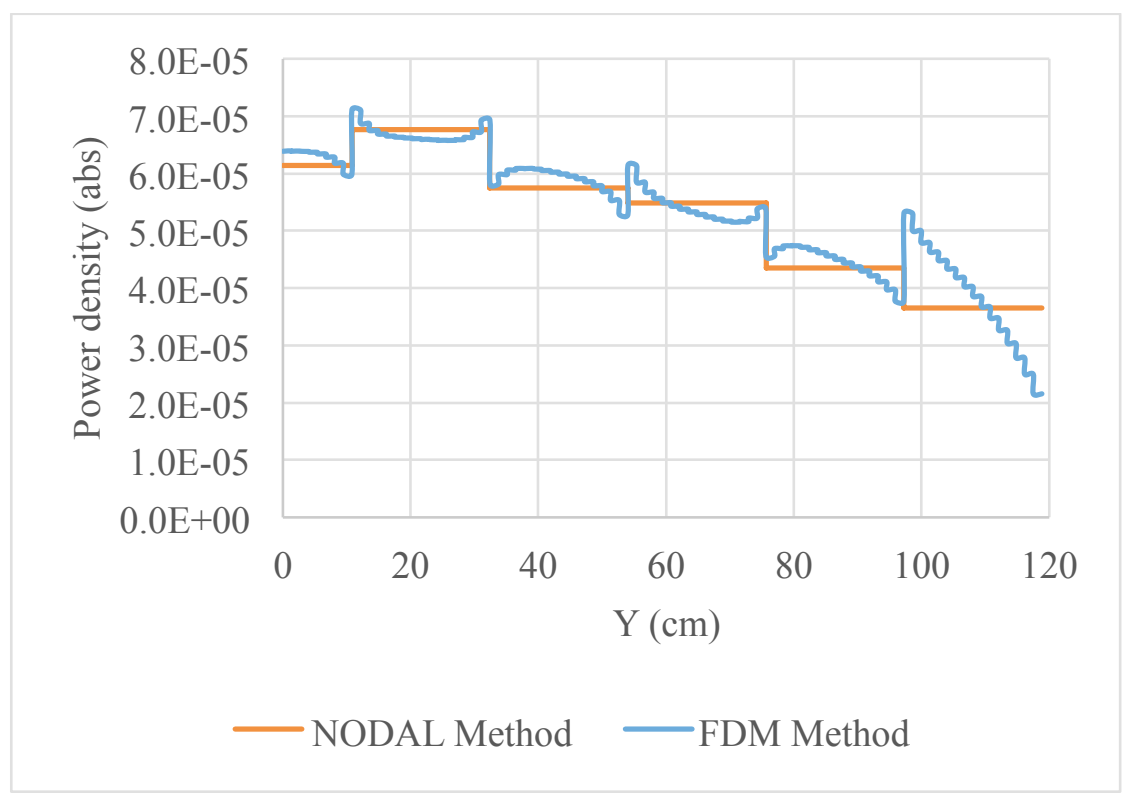

Fig. 9. Power density distribution at $\mathrm{X}=60 \mathrm{~cm}$ for the KOEBERG.

Distribution of power peaking factor RPPF of BIBLIS core from PWR-FUEL calculation are presented in Fig. 10. There is a maximum deviation of 0.021 or $1.75 \%$ in comparison to the reference value. 


\begin{tabular}{|c|c|c|c|c|c|c|c|}
\hline 1.091 & 1.101 & 1.242 & 1.220 & 1.081 & 0.982 & 1.094 & 1.014 \\
\hline 1.078 & 1.095 & 1.230 & 1.215 & 1.080 & 0.982 & 1.093 & 1.018 \\
\hline 0.013 & 0.006 & 0.012 & 0.005 & 0.001 & 0.000 & 0.001 & -0.004 \\
\hline 1.101 & 1.117 & 1.134 & 1.223 & 1.067 & 1.031 & 1.071 & 0.970 \\
\hline 1.095 & 1.105 & 1.128 & 1.213 & 1.065 & 1.027 & 1.073 & 0.974 \\
\hline 0.006 & 0.012 & 0.006 & 0.001 & 0.002 & 0.004 & -0.002 & -0.004 \\
\hline 1.242 & 1.134 & 1.122 & 1.105 & 1.120 & 0.923 & 0.930 & 0.824 \\
\hline 1.230 & 1.128 & 1.112 & 1.102 & 1.115 & 0.925 & 0.933 & 0.831 \\
\hline 0.012 & 0.006 & 0.010 & 0.003 & 0.005 & -0.002 & -0.003 & -0.007 \\
\hline 1.220 & 1.223 & 1.105 & 1.160 & 1.038 & 0.950 & 0.765 & 0.545 \\
\hline 1.215 & 1.213 & 1.102 & 1.155 & 1.042 & 0.951 & 0.773 & 0.549 \\
\hline 0.005 & 0.010 & 0.003 & 0.005 & -0.004 & -0.001 & -0.008 & -0.004 \\
\hline 1.088 & 1.067 & 1.120 & 1.039 & 1.122 & 0.992 & 0.874 & \\
\hline 1.060 & 1.065 & 1.115 & 1.042 & 1.124 & 1.005 & 0.883 & \\
\hline 0.028 & 0.002 & 0.005 & -0.003 & -0.002 & -0.013 & -0.009 & \\
\hline 0.982 & 1.031 & 0.923 & 0.950 & 0.992 & 1.199 & 0.684 & \\
\hline 0.982 & 1.027 & 0.925 & 0.951 & 1.005 & 1.220 & 0.689 & \\
\hline 0.000 & 0.004 & -0.002 & -0.001 & -0.013 & -0.021 & -0.005 & \\
\hline 1.094 & 1.071 & 0.930 & 0.765 & 0.874 & 0.684 & & \\
\hline 1.093 & 1.073 & 0.933 & 0.773 & 0.883 & 0.689 & & \\
\hline 0.001 & -0.002 & -0.003 & -0.008 & -0.009 & -0.005 & \multirow{4}{*}{\multicolumn{2}{|c|}{$\begin{array}{l}\text { Reference } \\
\text { PWR-FUEL } \\
\text { Difference }\end{array}$}} \\
\hline 1.014 & 0.970 & 0.824 & 0.545 & & & & \\
\hline 1.018 & 0.974 & 0.831 & 0.549 & & & & \\
\hline-0.004 & -0.004 & -0.007 & -0.004 & & & & \\
\hline
\end{tabular}

Fig. 10. RPPF comparison of PWR-FUEL results to BIBLIS core.

Calculation results of group neutron flux and power density distribution by nodal and finite difference are presented in Fig. 11 and 12. There is small differences of power distribution by these two methods. The BIBLIS-2D core has 7 sort of homogenized fuel assemblies (FA) that has different composition of material and with a dimension of $23.1226 \mathrm{~cm} \times 23.1226 \mathrm{~cm}$. The assemblies are surrounded by water reflector (Zona 3 ) with similar dimension. By RPPF deviation of $1.75 \%$, it can be said that the PWR-FUEL code also in a very good agreement with BIBLIS-2D model.

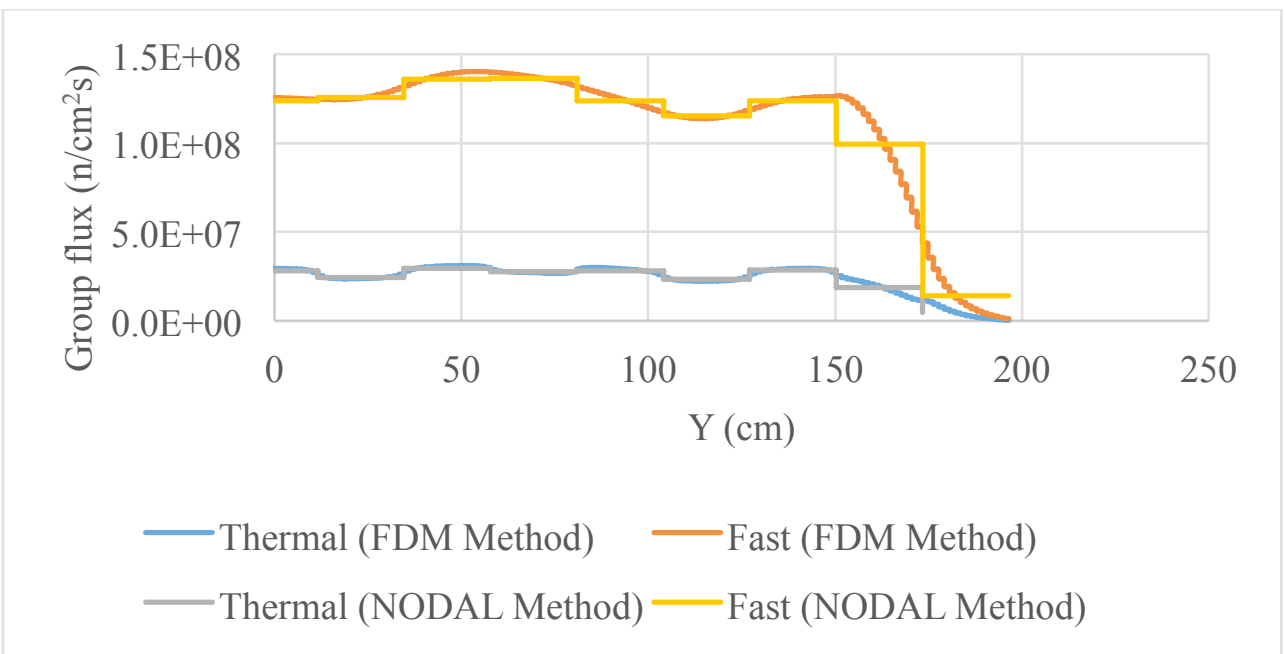

Fig. 11. Group neutron flux distribution at $\mathrm{X}=0 \mathrm{~cm}$ for the BIBLIS core. 


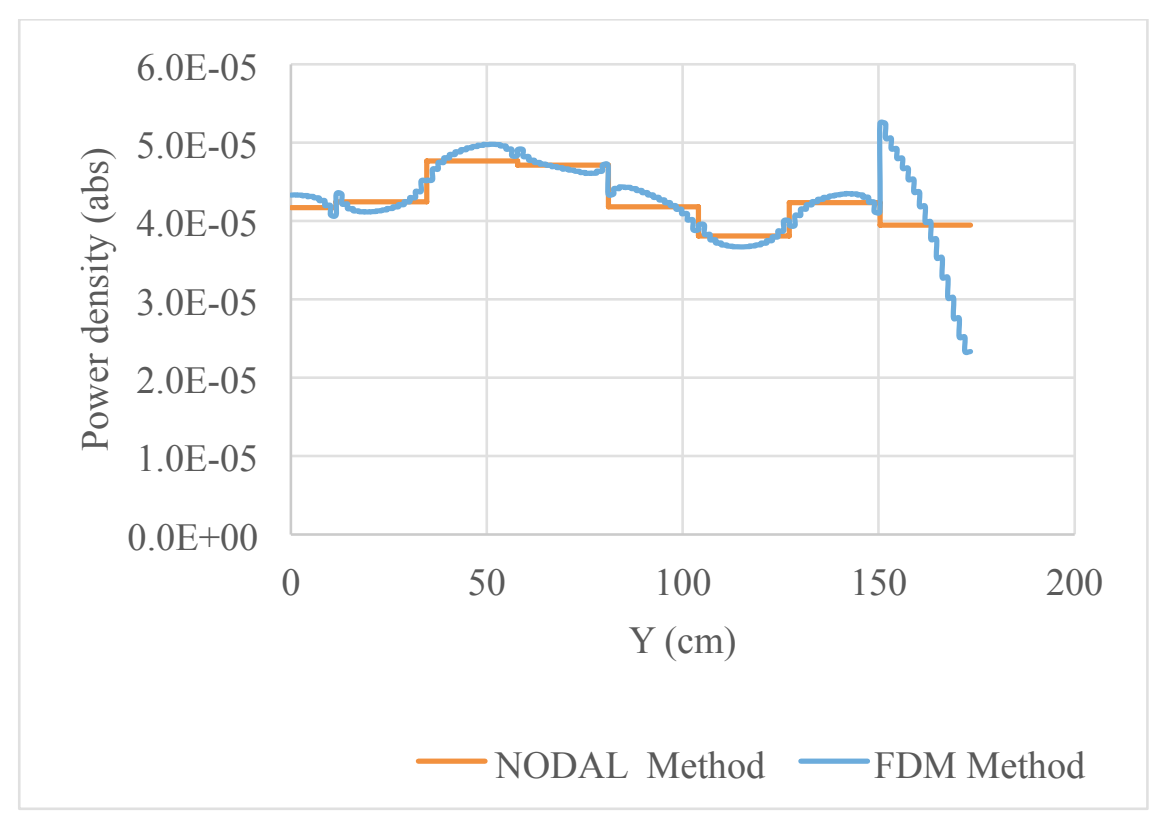

Fig. 12. Power density distribution at $\mathrm{X}=60 \mathrm{~cm}$ for the BIBLIS core.

\section{CONCLUSION}

Benchmark calculation of PWR-FUEL Code for cases of IAEA-2D, KOEBERG-2D and BIBLIS-2D cores for parameter of criticality and power peaking factor give very satisfied results. It is shown by maximum deviation of $0.014 \%$ for criticallity of those three cores. While for power peaking factor benchmarking, the maximum difference is about $1.75 \%$. The PWR-FUEL has shown a very good accuracy for calculating the criticallity or effective multiplication coefficient and power peaking factor. It has been proved by benchmark calculation for three different cores that have diferent configurations and number of neutron energy group. The PWR-FUEL code gives the same accuracy either by nodal or finite difference methods. Hence, the PWR-FUEL code is ready to be used for the in-core fuel management of real PWR.

\section{ACKNOWLEDGEMENT}

The authors thank to the Head of PTKRN and Syaiful Bakhri, PhD and the staff of Reactor Physics and Technology Division, PTKRN-BATAN for financial support using DIPA in the year of 2017 and their cooperation in conducting this research.

\section{REFERENCES}

1. Pinem S., Surbakti T. Analysis on Neutronic Parameters of The Ap1000 Reactor Core. in: Prosiding Seminar Nasional Teknologi Energi Nuklir 2016. 2016. pp. 569-75.

2. Pinem S., Sembiring T.M., Tukiran, Deswandri, Sunaryo G.R. Reactivity Coefficient Calculation for AP1000 Reactor Using the NODAL3 Code. J. Phys. Conf. Ser. 2018. 962(1):1-8.

3. Kuntoro I., Pinem S., Sembiring T.M. Analysis of Reactivity Coefficient Change Due To Burn Up in Ap1000 Reactor Core Using Nodal3. Tri Dasa Mega. 2017. 19(3):131.

4. Susilo J., Pane J.S. Fuel burn-up distribution and transuranic nuclide contents produced at the first cycle operation of ap1000. Tri Dasa Mega. 2016. 18(2):101-11. 
5. Liem P.H., Pinem S., Sembiring T.M., Tran H. Status on development and verification of reactivity initiated accident analysis code for PWR (NODAL3). Nucl. Sci. Technol. 2016. 6(1):1-13.

6. Pinem S., Sembiring T.M., Liem P.H. The verification of coupled neutronics thermalhydraulics code NODAL3 in the PWR rod ejection benchmark. Sci. Technol. Nucl. Install. 2014. 2014:1-9.

7. Isnaini M.D., Widodo S., Subekti M. The thermal-hydraulics analysis on radial and axial power fluctuation for ap1000 reactor. Tri Dasa Mega. 2018. 2015:79-86.

8. Ekariansyah A.S. Analisis kondisi teras reaktor daya maju AP1000 pada kecelakaan small break loca. Tri Dasa Mega. 2015. 17(2):87-98.

9. Andi Sofrany Ekariansyah, Surip Widodo, Susyadi, D.T. Sony Tjahyani H.T. Verifikasi Kecelakaan Hilangnya Aliran Air Umpan Pada Reaktor Daya PWR Maju. Tri Dasa Mega. 2012. 14(2):76-90.

10. Moghaddam N.M., Fadaei A.H., Zahedi E. Evaluating the effect of using different sets of enrichment for FAs on fuel management optimization using CA. Ann. Nucl. Energy. 2011. 38(4):835-45.

11. Hill N.J., Parks G.T. Pressurized water reactor in-core nuclear fuel management by tabu search. Ann. Nucl. Energy. 2015. 75:64-71.

12. Aghaie M., Nazari T., Zolfaghari A., Minuchehr A., Shirani A. Investigation of PWR core optimization using harmony search algorithms. Ann. Nucl. Energy. 2013. 57:1-15.

13. Mahmoudi S.M., Aghaie M., Bahonar M., Poursalehi N. A novel optimization method, Gravitational Search Algorithm (GSA), for PWR core optimization. Ann. Nucl. Energy. 2016. 95:23-34.

14. PWR-FUEL PWR In-Core Fuel Management Code. User Guide. 2012.(August)

15. Sembiring T.M., Pinem S. The validation of the NODAL 3 code for static cases of the PWR benchmark core. J. Nucl. Sci. Technol. Ganendra. 2012. 15(2):82-92.

16. Pinem S., Sembiring T.M., Liem P.H. NODAL3 Sensitivity Analysis for NEACRP 3D LWR Core Transient Benchmark (PWR). Sci. Technol. Nucl. Install. 2016. 2016:1-11.

17. Pinem S., Sembiring T.M., Tukiran Verifikasi Program PWR-FUEL Dalam Manajemen Bahan Bakar PWR. J. Sains dan Teknol. Nukl. Indonesia. 2015. 16(1)

18. E.Z. Muller Z.J.W. Benchmarking with the multigroup diffusion high-order response matrix method. Ann. Nucl. Energy. 1991. 18(9):535-44.

19. Guessous N., Akhmouch M. Higher order analytical nodal methods in response-matrix formulation for the multigroup neutron diffusion equations. Ann. Nucl. Energy. 2002. $29: 1765-78$

20. Meneses A.A. de M., Araujo L.M., Nast F.N., da Silva P.V., Schirru R. Application of metaheuristics to Loading Pattern Optimization problems based on the IAEA-3D and BIBLIS-2D data. Ann. Nucl. Energy. 2018. 111:329-39.

21. Yadav R.D.S., Gupta H.P. Optimization Studies of Fuel Lading Pattern for a Typical Pressurized Water Reactor (PWR) Using Particle Swarm Method. Ann. Nucl. Energy. 2011. 38(9):2086-95. 